\title{
The Importance and Scope of Metaphor in Representing a Central Buddhist Image: The Treasure Tower
}

\begin{abstract}
In chapter 11 of the ancient Buddhist text the Lotus Sutra, an amazing cosmic movement takes place: a colossal treasure tower rises up out of the earth and stands suspended in the air, at the centre of the universe. Seven centuries ago, Nichiren asserted to Abutsu-bo, a disciple of his: "Abutsu-bō is [...] the Treasure Tower itself, and the Treasure Tower is Abutsu-bō himself. No other knowledge is purposeful." Instead of dazing his disciple with complex theories, the master presented a magnificent metaphor related to insight into the disciple's human condition. Paul Ricœur points out that the metaphor makes and remakes reality; he analyses the metaphor's referential value and concludes that metaphor may be seen as a model for changing our way of looking at things, of perceiving the world. By hearing such a metaphor, so cheering but also so powerful, the disciple would quickly understand the significance of its terms. No other explanation would be necessary for him to grasp them.
\end{abstract}

Keywords: allegory, Buddhahood, Buddhism, metaphor, speech acts

\section{Introduction}

In the Lotus Sutra, one of the most important sacred Buddhist writings, Shakyamuni ${ }^{1}$ exposed the nature of enlightenment through an allegory, the Treasure Tower. Two thousand years afterwards, a disciple named Abutsu-bo asked the monk Nichiren about the meaning of that tower. Instead of an allegory, Nichiren used another rhetorical device, the metaphor. In the allegory, several images representing different philosophical concepts are displayed. In a metaphor, an idea or concept is linked to a subject.

This article aims to contribute to the study of cultural images and their linguistic representation. We shall combine functional linguistic theories and pragmatics: a definition of allegory, philosophical studies on metaphor (Paul Ricœur

1 Shakyamuni is another name for Siddhartha Gautama. He lived in Nepal at some point between the sixth and fourth centuries BCE and would one day become known as Buddha (the "enlightened one" or "the awakened"). 
and Hans Blumenberg), and speech act theory (J. L. Austin). The article will help explain the interpretative potentialities of the metaphor in the proposition expressed by Nichiren.

\section{The Treasure Tower as allegory}

An allegory is a representation of an abstract or spiritual meaning through concrete or material forms ("allegory" n.d.). An intertextual reading is necessary in order to identify a deeper or more abstract meaning. According to Cicero in De oratore, the allegory is a system of metaphors. One way to distinguish a metaphor from an allegory is that proposed by ancient rhetoricians: the former covers only separate terms; the latter may be extended to expressions or to whole texts (Ceia 2009). One more aspect can be mentioned following Goethe: the allegory transforms the phenomenon into a concept and the concept into an image, but in such a way that the concept remains always expressible in the image (cited in Selhan 2000, 440). In the scene from the Lotus Sutra that we describe below, it will be possible to easily identify such aspects of the allegory.

The Treasure Tower appears in chapter 11 of the Lotus Sutra. This sacred text of Mahayana Buddhism was venerated for several centuries in various regions of East Asia. ${ }^{2}$ It is believed to have been formulated in a dialect of India or Central Asia and translated into Sanskrit afterwards. The only exact date that can be associated with the Lotus Sutra is that of 255 CE, the year of its first translation into Chinese (Watson 1993, x). But it is through the Chinese version produced in 406 by the Central Asian scholar-monk Kumarajiva that it has become widely known and read in China and the other countries within the Chinese sphere of cultural influence. This version has been universally acknowledged as the most authoritative and felicitous in Chinese (Watson 1993, ix-x).

The Lotus Sutra starts by describing Eagle Peak near the city of Rahagrija, where the Buddha preached. In these opening sentences we are still in the world of historical reality or possibility, in a setting where Shakyamuni very probably did in fact propound his doctrines between the sixth and fourth centuries BCE. Then, however, a staggering number and variety of human, non-human, and

2 The Mahayana (Skt "Greater Vehicle") movement arose within Indian Buddhism around the beginning of the common era, and by the ninth century became the dominant influence on the Buddhist cultures. Mahayana Buddhism - which includes the teachings of the Lotus Sutra - considers that compassionate practice is a means of attaining enlightenment. 
heavenly beings gather to hear the Buddha's teachings. ${ }^{3}$ All these scenes seem to create a new paradigm that transcends all ordinary concepts of time, space, and also possibility. After several astounding events, impressing due to their cosmic scale, the Buddha begins to preach.

This is the expected moment when the Buddha will present a more accurate teaching that will surpass his earlier pronouncements, which had only provisional validity. When the disciples ask why he did not expound it before, he replies that they were not yet prepared to accept it. And the Buddha bestows on many of them, both men and women, a prophecy of the attainment of Buddhahood in a future existence. Then, a cosmic movement occurs: the Treasure Tower, of huge dimensions, rises up out of the earth and stands suspended in the air. Various kinds of precious objects adorn it. "All four sides emitted a fragrance of tamalapatra and sandalwood that pervaded the whole world. Its banners and canopies were made of seven treasures, namely, gold, silver, lapis lazuli, seashell, agate, pearl, and carnelian" (The Lotus Sutra 1993, 170). Inside the tower is a Buddha from the past, Many Treasures Buddha, who made a vow: that he would reappear with this Treasure Tower whenever the Lotus Sutra is preached; he would "come forth and appear in that spot to testify to the sutra and praise its excellence" (The Lotus Sutra 1993, 171). Many Treasures Buddha praises Shakyamuni for preaching the Lotus Sutra. After Shakyamuni has performed several actions in different worlds, Many Treasures Buddha offers him half of his seat in the Treasure Tower, and at once Shakyamuni enters the tower and sits beside him.

The Treasure Tower represents the supreme dignity of Buddhahood, a state of life that must not be understood as mystic or transcendent. Instead, this is a condition of life in which people enjoy wisdom, vitality, self-trust, and other positive conditions that enable them to perform daily activities with integrity and a consciousness of life's purpose (Rubio 2008, xxxvi). The seven jewels or treasures are "the correct teaching, believing it, keeping the precepts, engaging in meditation, practicing assiduously, renouncing one's attachments, and reflecting on oneself" (Nichiren 1999, 317). Many Treasures Buddha represents the world of objective reality that has always existed. This reality refers to the "eternal truth" (Ikeda et al. 1997, 17; my translation) that will be formulated later as the universal law that governs life. Buddha Shakyamuni represents the mortal Buddha, or the active and manifested Buddhahood in this real and ephemeral world. And the act of sitting beside Many Treasures Buddha represents the fact that the two aspects of

3 For example, the text mentions, as Watson (1993, xvi) puts it, "beings or worlds that are as numerous as the sands of millions and billions of Ganges rivers"; these numbers are intended to impress on us the impossibility of measuring the immeasurable. 
the Buddha - eternity and transience - are one thing. Both Buddhas denote the principles of reality (the universal law that governs life) and wisdom (the capacity of perceiving that same law in oneself and in every manifestation of life). Daisaku Ikeda, a contemporary Buddhist philosopher, explains that "the only realm where the eternal law can manifest itself is here and now" (in Ikeda et al. 1997, 17; my translation). According to the Buddhist point of view, there are not two planes, a subjective and an objective one; on the contrary, both constitute an essential unity (Ikeda et al. 1997, 15).

With the appearance of the Treasure Tower, a new worldview, completely different from previous teachings, is being presented. Shakyamuni preaches, through a lavish allegory, that a common person may manifest a magnificent dignity in his/her brief life; and that such dignity should reflect upon his/her objective world. The conceptual framework that supports this worldview entails great complexity.

\section{The Treasure Tower as metaphor}

Buddhist philosophy arrived in Japan in the sixth century CE and spread rapidly within the country in different branches. In many cases, it fused with Shinto or shamanistic thought, and it mingled with pseudo-magic practices that aimed to cure illness or to obtain material benefits (Rubio 2008, xxv).

An important Buddhist monk in Japan was Nichiren, who lived in the thirteenth century. When he was sixteen years old, he was ordained as a priest. The fact that Buddhist teachings were divided into many schools inspired Nichiren to visit every temple to read its texts in search of the one that bore the essential spirit. He found it in the Lotus Sutra. He could also elucidate its essence, which he summarized in the phrase Nam-myoho-renge-kyo. ${ }^{4}$ These words also stand for the universal law of life. Nichiren pronounced this phrase for the first time when he was thirty-two. He was convinced that, by chanting Nam-myojo-renge-kyo, every human being would be able to manifest enlightenment (Rubio 2008, xxxiii). And he disseminated it as a way to ensure happiness for mankind and peace in the world.

\footnotetext{
4 Nam comes from the Sanskrit namas, meaning "to devote or dedicate oneself." Myo can be translated as "mystic" or "wonderful," and ho means "law." This law is described as mystic because it is difficult to comprehend that all common people can awaken to the consciousness of Buddha. Renge means "lotus blossom," which is pure and fragrant, unsullied by the muddy water in which it grows. Similarly, the beauty and dignity of our humanity is brought forth amidst the sufferings of daily reality. Kyo literally means "sutra," and here indicates the Mystic Law likened to a lotus flower, the fundamental law that permeates life and the universe, the eternal truth.
} 
Nichiren wrote philosophical treatises but also many letters in response to followers' questions. His style in the letters was intimate and personal; his relationship with his followers was a close one. One of his disciples, Abutsu-bo, once sent him coins - an offering to the Treasure Tower - and a letter in which he asked about the meaning of the tower and of Many Treasures Buddha. In response, Nichiren explained the relationship between the closed tower and theoretical teaching, and the open tower and essential teaching. The latter, which is the more important, reveals two elements of reality: first, the immense innate potential of life (represented by Many Treasures Buddha) and, second, the wisdom to perceive such reality (represented by Buddha Shakyamuni). These two elements are essential aspects of Buddhahood. Nichiren also said that the appearance of the Treasure Tower indicated that, when hearing the Lotus Sutra, disciples could perceive for the first time the Treasure Tower in their own lives. And then he stated his most important phrase: "Abutsu-bō is therefore the Treasure Tower itself, and the Treasure Tower is Abutsu-bō himself. No other knowledge is purposeful" (Nichiren 1999, 299).

Nichiren explains that the disciple might think that he had offered gifts to the Treasure Tower of Many Treasures Buddha; but instead, he was offering them to himself. This means that, in sending offerings to his master and in manifesting so much interest in learning about his philosophy, he was accumulating good causes for his own happiness. And the master emphasizes that Abutsu-bo should chant Nam-myoho-renge-kyo with the conviction that he himself was a Buddha. Instead of dazing the disciple with complex theories, the master presented a magnificent metaphor to enhance the disciple's insight into his own human condition.

\subsection{Metaphor}

A metaphor is a poetically or rhetorically ambitious use of words, a figurative - as opposed to literal - use. The metaphor has attracted more philosophical interest and provoked more philosophical controversy than any other of the traditionally recognized figures of speech (Hills 2011). When we speak of a metaphor, we are talking about two things at once, two different and disparate subject matters that are mingled to produce an enhanced and unpredictable effect. One of these subject matters is already under discussion, or at least already up for consideration when a speaker resorts to metaphor in the first place. This is the metaphor's primary subject, in our case: Abutsu-bo. The second subject matter is introduced to temporarily enrich our resources for thinking and talking about the first. This is the metaphor's secondary subject: the Treasure Tower. The maker of a meta- 
phor (or the metaphor itself) likens the primary subject to the secondary subject: Nichiren likens Abutsu-bo to the Treasure Tower.

In the process of creating a metaphor, there is a deviation from a literal meaning of a word towards a new, free sense; a transposition of the meaning of a word to another word, a meaning that originally did not belong to it. The reader must perform an interpretation process through which the first meaning is rejected in order to apprehend the new meaning suggested by the metaphor and clarified by the context into which it is inserted.

Metaphors share with similes the notion of likeness. From the recipient's point of view, a simile pursues a logical coherence between the two elements compared, which is reinforced by the use of "like" or "as." The metaphor, however, involves an abstraction in sensitivity or imagination due to its rupture from discursive logic and the freedom it gives to the speaker. Thus, the metaphor involves a greater complexity; it is not simply an abbreviated comparison. In fact, the metaphor may include two terms with dissimilar and/or unlike symbolic references not directly comparable with each other in an attempt to recreate a representation (or understanding) of the world (outer reality) or spirit (inner reality; Mendes 2010).

\subsection{Absolute metaphors}

Hans Blumenberg, a German philosopher and intellectual historian, devoted much of his work to the study of metaphor. He analysed the role metaphors play in philosophical language. In Paradigms for a Metaphorology (Blumenberg 2010), originally published in 1960, Blumenberg examines the relationship between metaphors and concepts. He argues for the existence of "absolute metaphors" that cannot be translated back into conceptual language. These metaphors answer the supposedly naive, theoretically unanswerable questions whose relevance lies in the fact that they cannot be ignored since they are implicit in the ground of our existence. These metaphors leap into unknown fields that concepts are unable to cover.

As a historical researcher, Blumenberg would avoid the question of absolutes. However, he could not ignore the question a quo, asked by Heidegger, a question linked with the notion of origin. The origin of life, for example, is very complex and is a point that cannot be ignored from an anthropological point of view. Metaphor mediates between Dasein ${ }^{5}$ and the absolute that arises from philosophical anthropology.

5 Heidegger uses the expression Dasein to refer to the experience of being that is peculiar to human beings, a form of being that is aware of and must confront limitations of their understanding the world. 
The relationship between reason and rhetoric in absolute metaphor may be defined by Blumenberg's refusal to accept Descartes's view that everything can be defined with clear, precise, unchanging concepts. Blumenberg's un-Cartesian view of history is inherent in the concept of the absolute metaphor, because such metaphors make up the "substructure of thought, [...] the underground, the nutrient of systematic crystallizations" (Adams 1991, 156). The absolute metaphor is a "catalytic sphere, from which indeed the world of concepts continually enriches itself, but without thereby transforming or consuming this supporting material" (Adams 1991, 156).

The major quest for Buddhists has always been related to the attainment of Buddhahood. This is possible when practitioners perceive the ultimate reality; and they hope that such perception will enable them to find full spiritual satisfaction in life, in other words to surpass the psychological as well as the social barriers that hinder the way towards full enjoyment of life.

When Abutsu-bo asked Nichiren about the appearance of the Treasure Tower, he was probably expecting a philosophical explanation. The master replied in two different ways. He first explained the components of the allegory that represented the Treasure Tower. But, he said, "it is extremely complex" (Nichiren 1999, 299) to explain. And then he stressed that the appearance of the Treasure Tower indicated that “on hearing the Lotus Sutra" (Nichiren 1999, 299), listeners could perceive, for the first time, the Treasure Tower within their own lives.

The most important aspect of the Treasure Tower is transmitted through metaphorical statements: (1) The daimoku of the Lotus Sutra is the Treasure Tower, ${ }^{6}$ and the Treasure Tower is Nam-myoho-renge-kyo, and (2) those who chant Nammyoho-renge-kyo are themselves the Treasure Tower and, likewise, are themselves Buddhas; therefore, as a consequence of prior statements, Abutsu-bo is the Treasure Tower and the Treasure Tower is Abutsu-bo. According to this worldview, the daimoku is the essential factor. And the person who chants daimoku - both the disciple and the Buddha - is the Treasure Tower. So, the daimoku and the person who chants daimoku (disciple or Buddha) are the Treasure Tower, that is, the most valuable entities in the world.

In the Lotus Sutra, a Buddha named Many Treasures, seated in the Treasure Tower, praises Shakyamuni for his preaching. The Buddha, the teaching, and the disciples are presented as separate entities. Nichiren, however, fuses the teaching (Nam-myoho-renge-kyo), the disciple (Abutsu-bo), the Buddha (Many Treasures or Shakyamuni), and the Treasure Tower into one entity. The disciple who chants

6 Daimoku is the practice of chanting Nam-myoho-renge-kyo. 
daimoku is the Buddha and is also the Treasure Tower. The Treasure Tower as absolute metaphor introduces a whole new conception of the world and of life. The master's intention is that Abutsu-bo grasp the meaning, that he feel it, and that he incorporate it.

\subsection{Semantic metaphor theory and psychological theories}

Paul Ricœur (1978), in accordance with Blumenberg's view, analyses the metaphor's referential value and points out that the metaphor makes and remakes reality, since it functions as a vehicle for changing our way of looking at things, of perceiving the world. To better understand how metaphors work, Ricœur mentions the interaction theory (in contrast to substitutive theory) of Max Black. According to this, the bearer of the metaphorical meaning is no longer the word but the sentence as a whole, since there is interaction between a logical subject and a predicate. Therefore, metaphor should be described as a deviant predication rather than a deviant denomination - the bearer of the metaphorical meaning being no longer the word but the sentence as a whole. Even though the effect of sense is focused on the word, the production of sense is borne by the whole sentence.

Besides the semantic theory of metaphor - its capacity to provide information about reality - its decisive feature is semantic innovation, thanks to which a new pertinence is established in such a way that an utterance "makes sense" as a whole. According to Ricœur, it must be emphasized that there is a functioning of similarity and of imagination that is immanent in the predicative process itself. Therefore, the work of establishing resemblance that takes place in the metaphor process has to be in accordance with the deviance and oddness, but also freshness, of the semantic innovation. It is important to understand how resemblance works in the production of meaning. Ricœur uses a spatial metaphor in his explanation: the new congruence proper to a meaningful metaphorical utterance proceeds from the kind of semantic proximity obtained between terms in spite of their distance. This movement from the far to the near requires an explanation. There is a pictorial or iconic moment in this work of establishing resemblance.

The process of comprehension can be completed by a psychological component such as the "image" or "feeling." Ricœur affirms that imagination does not merely schematize the predicative assimilation of terms; it rather contributes to the projection of new possibilities for redescribing the world. For Ricœur, this projective role of fiction is quite different from the so-called mental image that provides a re-presentation of things already seen. Fiction addresses itself to deeply rooted potentialities of reality. Fiction presents in a concrete mode the split struc- 
ture of the reference pertaining to the metaphorical statement. It both reflects and completes it.

Another important component of metaphor is "feeling." To feel, in the emotional sense of the word, is to make ours what has been put at a distance by thought in its objectifying phase. These feelings are not merely inner states but interiorized thoughts. Thus, feeling is not opposite to thought. Ricœur returns to Heidegger's analysis of Dasein, which states that feelings have ontological bearing, that they are ways of "being-there," of "finding" ourselves within the world. But this makes sense only to the extent that it is paired with the split structure of reference in poetic discourse.

Nichiren, the maker of the metaphor, intends that Abutsu-bo be able not only to understand but also to feel the impressive meaning of the Treasure Tower as the representation of Buddhahood in a common human being. The intention of Nichiren is that the disciple understands not the Treasure Tower as a philosophical concept, but the meaning of the whole worldview: that he is already a Buddha in his present form, as an ordinary person. In other words, the attainment of Buddhahood is not a promise to be fulfilled in a distant future. Nichiren's words have a pragmatic twist, since they serve as a speech act in Austin's sense: the metaphor helps the meaning to be grasped more easily - it contributes to producing a perlocutionary effect (that the disciple undertake the internal search for his own Buddhahood).

\section{Speech acts}

According to Austin (1962), there is a threefold distinction among the kinds of acts that are performed when language is put to use: locutionary, illocutionary, and perlocutionary acts. Locutionary acts are acts of speaking, such as uttering certain sounds, using particular words in conformity with the grammatical rules of a particular language and with certain senses and certain references. An utterance is made with the intention of performing a certain illocutionary act: to state or to assert, to order or to request (usually by using imperative sentences), or to ask (usually by using interrogative sentences). The third of Austin's categories is the perlocutionary act, which is a consequence or by-product of speaking. Perlocutionary acts consist of producing effects upon the thoughts, feelings, or actions of the addressee(s) or other parties.

In Nichiren's utterance "Abutsu-bō is [...] the Treasure Tower itself, and the Treasure Tower is Abutsu-bō himself," we can identify the metaphor as part of the locutionary act. As an illocutionary act, the sentence denotes Nichiren's intention 
of explaining what the Treasure Tower is, and also of persuading the disciple that he is a Buddha. The expected perlocutionary effect, which we cannot verify, is that Abutsu-bo view himself as a Buddha. Nichiren's declaration denotes a highly emotive personal interaction. Abutsu-bo should not only understand that the Treasure Tower is a representation of Buddhahood; he should view himself as a Buddha. And not only Abutsu-bo. Since Nichiren states that "those who chant Nam-myoho-renge-kyo are themselves the Treasure Tower, and, likewise, are themselves the Thus Come One Many Treasures” (Nichiren 1999, 299), every disciple who chants Nam-myoho-renge-kyo is a Buddha. The disciple should perceive in his/ her own life the magnificence of the Buddhahood - he/she should feel it, he/she should rejoice after hearing it. This seems to be the intended perlocutionary act.

\section{Conclusion}

The profusion of images in the allegorical presentation of the Treasure Tower by Shakyamuni must have impressed the disciples. Philosophical explanations of all the concepts presented in that allegory were provided by scholar-monks in thorough studies across many centuries. We can therefore affirm that the allegory allowed the presentation of an extremely complex philosophical system. The strategy of using the allegory was interesting since it allowed the presentation of the whole system for the first time to common people, who ignored it.

Two thousand years later, Nichiren investigated innumerable Buddhist texts, which included not only the sutras but also theoretical studies developed in different periods and areas in which Buddhism was propagated. And his conclusions may be summarized in his reply to Abutsu-bo: because he chants Nam-myohorenge-kyo, Abutsu-bo is the Treasure Tower, and no other knowledge is important. Carlos Rubio, a specialist in Japanese literature, affirms that it was noteworthy that Nichiren considered it most important to internalize symbols and doctrine in general. This was a remarkable attitude that contrasted with the formalism of contemporaneous Buddhist schools (Rubio 2008, xxxvii).

The metaphor used by Nichiren aimed to further the comprehension of an ultimate reality that was completely different from the current representation of the world. Nichiren presented the oneness of the common mortal and the eternal life; they are not different instances but coexist. Through the internalization of the symbol, it may be possible to find the dimension of Buddhahood - the great wisdom and compassionate love that exists forever in the human being - and this consciousness should help in finding a different way of interacting with the surrounding world. 
The fictional aspect of the metaphor allows it to recreate a completely different conception of reality. Furthermore, the metaphor does not work as an independent word; its most important factor is the interaction between a logical subject and the predicate. It is important to recall here that Max Black (cited in Ricœur 1978, 145) said that the bearer of the metaphorical meaning is not the word but the whole sentence. In this light, we can understand even better the expressive force of the statement "Abutsu-bō is [...] the Treasure Tower." Nichiren was not interested in the truth written in books; instead, he searched for a vivid truth that could be internalized by the disciple.

At the closing conference of the 4th Latin American Course on Soka Buddhism, held in April 2017 in Buenos Aires, the Studies Department Chief of the Soka Gakkai International organization stated that the conclusion of all Buddhist studies is that all people who practice daimoku are Buddhas. But this seems to be a truth that cannot be easily experienced - and in that same vein we can understand Nichiren's effort in awakening the Treasure Tower in the soul of Abutsu-bo.

\section{Works cited}

Adams, David. "Metaphors for Mankind: The Development of Hans Blumenberg's Anthropological Metaphorology." Journal of the History of Ideas 1.1 (1991): 152-166. http:// www.jstor.org/stable/2709587 (10 May 2016).

“Allegory." Dictionary.com. n.d. www.dictionary.com/browse/allegory (10 June 2018). Austin, John L. How to Do Things with Words. London: Oxford University Press, 1962.

Blumenberg, Hans. Paradigms for a Metaphorology. Trans. Robert Savage. Ithaca: Cornell University Press, 2010.

Ceia, Carlos. "Alegoria." E-Dicionário de Termos Literários. Faculdade de Ciências Sociais e Humanas - Universidade Nova de Lisboa, 29 December 2009. http://edtl.fcsh.unl.pt/ encyclopedia/alegoria/ (15 May 2016).

Hills, David. “Metaphor.” Stanford Encyclopedia of Philosophy. 19 August 2011. http://plato. stanford.edu/entries/metaphor/ (25 April 2016).

Ikeda, Daisaku, Katsuji Saito, Takanori Endo, and Haruo Suda. “17. Nuestra vida es, en sí misma, la Torre de los Tesoros." La sabiduría del Sutra del loto: Diálogo sobre la religión en el siglo XXI. Trans. Soka Gakkai Translation Committee of Argentina. Vol. 9. Buenos Aires: Soka Gakkai Internacional de la Argentina, 1997. 2-27.

The Lotus Sutra. Trans. Burton Watson. New York: Columbia University Press, 1993.

Mendes, Paula. "Metáfora." E-Dicionário de Termos Literários. Faculdade de Ciências Sociais e Humanas - Universidade Nova de Lisboa, 20 June 2010. http://edtl.fcsh.unl.pt/ encyclopedia/metafora/ (1 November 2018).

Nichiren. The Writings of Nichiren Daishonin. Trans. Gosho Translation Committee. Tokyo: Soka Gakkai, 1999.

Ricœur, Paul. "The Metaphorical Process as Cognition, Imagination and Feeling." Metaphor. Spec. issue of Critical Inquiry 5.1 (1978): 143-159. 
Rubio, Carlos. "Introducción.” Los escritos de Nichiren Daishonin. By Nichiren. Trans. Comité de traducción del Gosho al español. Tokyo: Soka Gakkai, 2008. xix-xl.

Seihan, Azade. "Allegory as the Trope of Memory: Registers of Cultural Time in Schlegel and Novalis." Interpretation and Allegory: Antiquity to Modern Period. Ed. Jon Whitman. Boston: Brill, 2000. 437-450.

Watson, Burton. "Translator's Introduction.” The Lotus Sutra. Trans. Watson. New York: Columbia University Press, 1993. ix-xxii.

Christiane Kazue Nagao's most important life experiences were being a mother, becoming a Buddhist, and graduating in Literature at the University of Buenos Aires. The object of study that really caught her attention was life: what life is, its importance, and the best way to go through it. And both Buddhist philosophy and literature became her way of investigating life, with the aid of linguistic tools. That is her passion. 